\title{
Submarine Cables, the Internet Backbone, and the Trade in Services
} Zouheir El-Sahli, Qatar University

\section{Summary}

- Submarine cables are undersea digital bridges that allow ideas and information to move across space.

- Submarine cables are expensive infrastructure investments and their high costs raise the question about their economic returns, especially in developing countries.

- Namely, do submarine cables stimulate the trade in services and hence facilitate economic diversification in connecting countries?

- Using a novel data set for connecting the world countries by submarine cables, this study considers the variation in the number of submarine cables as well as the timing of connection to identify the effects of submarine cables.

- To deal with endogeneity, two novel instruments are developed.

- The results confirm that submarine cables stimulate services trade in some sectors.

- Benefits to developing countries are higher where more sectors expand their services trade and no sectors lose.

\section{Methodology}

- Estimate the following equation using panel data econometrics:

- Log trade $_{i t}=\beta_{0}+\beta_{1} \log$ NCable $_{i t}+\beta_{2} \log$ GDP $_{i t}+\beta_{3} \log$ goods trade ${ }_{i t}+$

$\beta_{4}$ Log Remoteness $i t+\beta_{5}$ GATS $_{i t}+\beta_{6}$ Rule of Law Lat $_{i t}+\mu_{i}+\mu_{t}+\epsilon_{i t}$

- In the above equation: I stands for exporter, $\mathrm{t}$ stands for year

- But endogeneity may be a problem for instance due to reverse causality:

\section{Trade Reverse causality Cables}

- To deal with this, instrumental variable approach is used

- The instruments are:

1. Trade weighted average sea distances

Weighted sea distances $s_{i t}=\log \Sigma_{i \neq j} \pi_{j t}$ seadistance $_{i j}$

2. Regional internet users: total regional internet users excluding the observation country

\section{Data}

- Raw submarine cables is obtained from TeleGeography.

- World services trade data are obtained from the OECD (OECD-WTO BATIS Database).

- Other control variables are obtained from the World Bank and CEPII.

\section{Results}

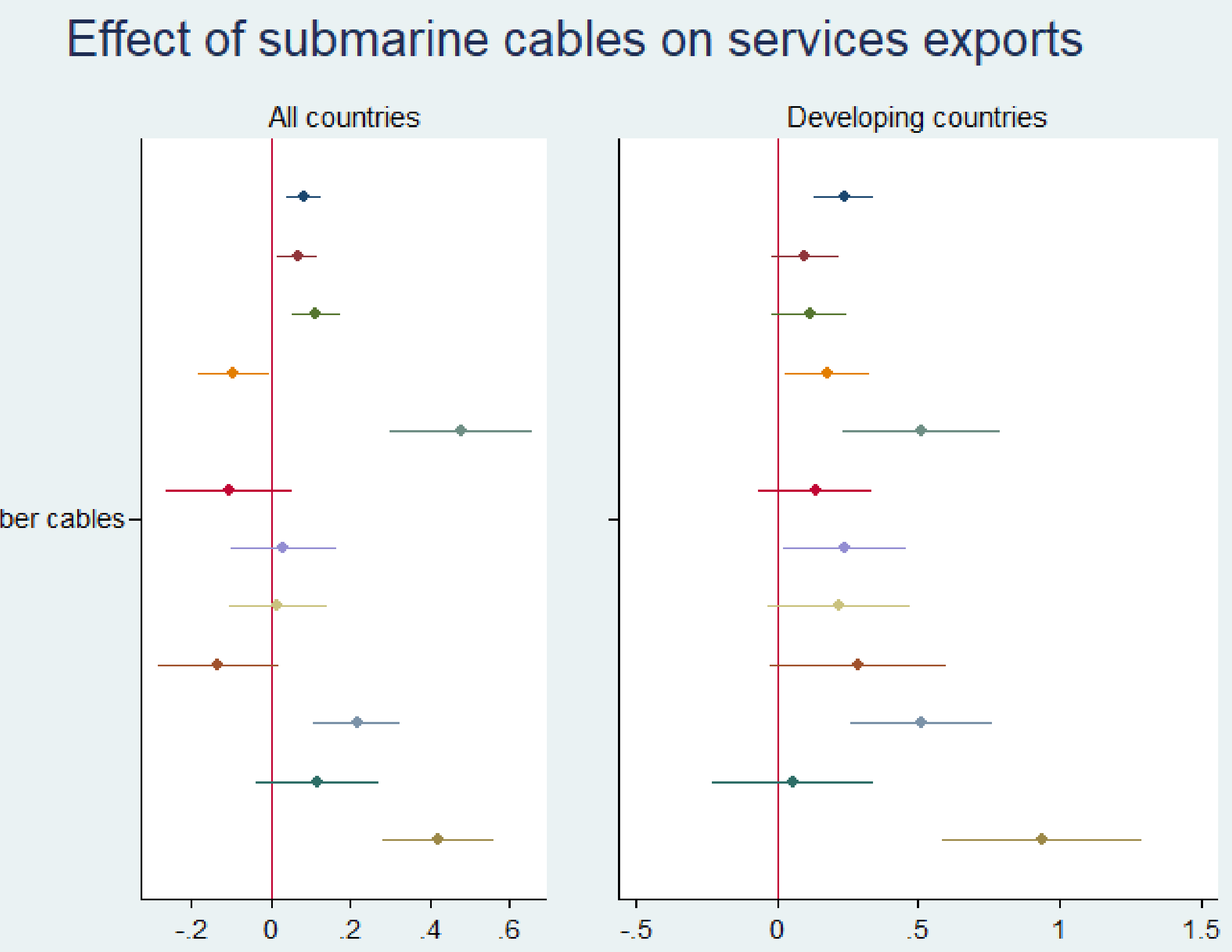

Effect of submarine cables on services imports
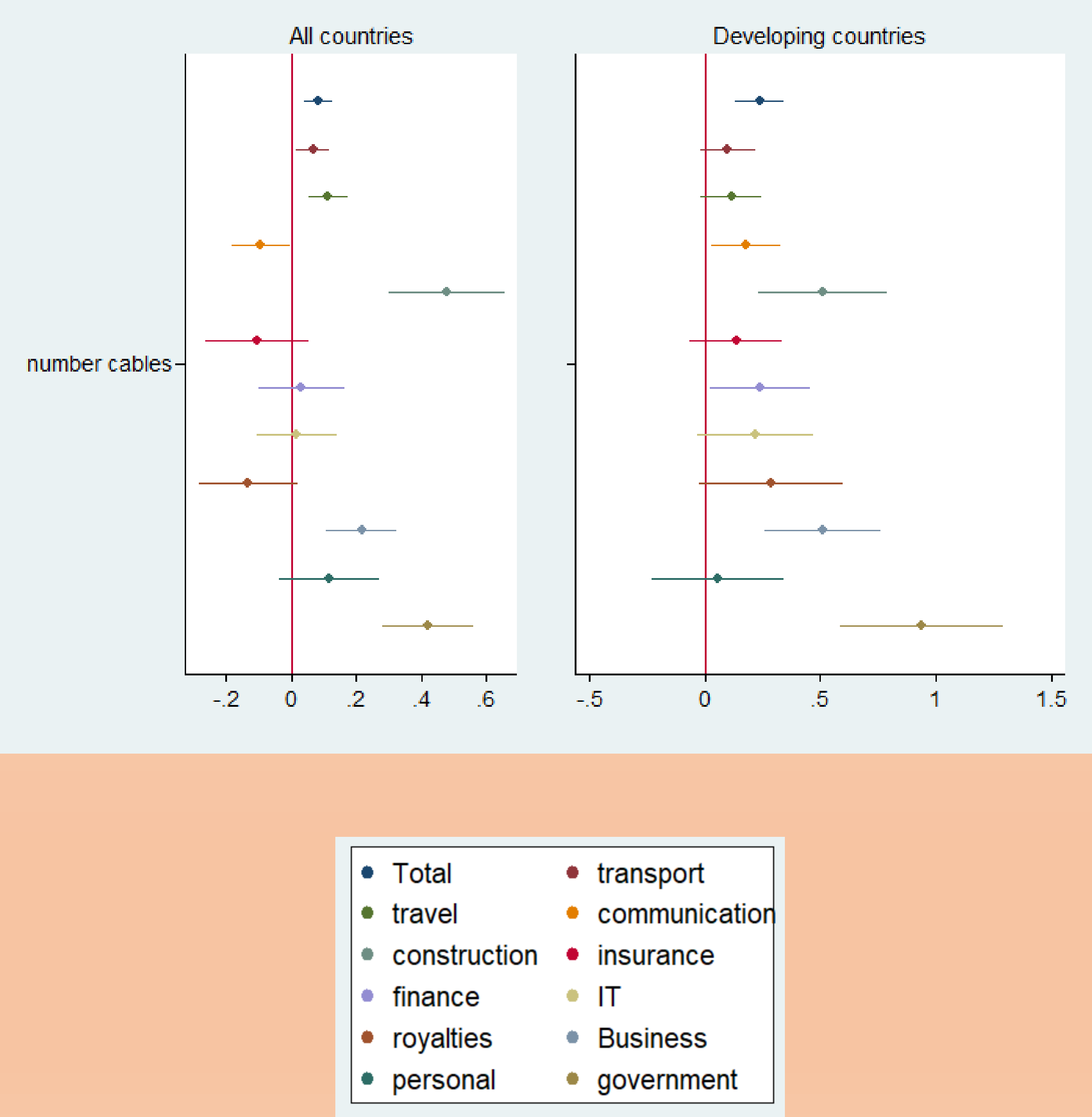

\section{Anecdotal Evidence}

$\begin{array}{lll}\text { Country } & \text { Cost } & \text { landlocked } \\ \text { Mauritius } & 0.84 & \text { No } \\ \text { Seychelles } & 1.6 & \text { No } \\ \text { South Africa } & 2.85 & \text { No } \\ \text { Gabon } & 3.42 & \text { No } \\ \text { Cape Verde } & 3.54 & \text { No } \\ \text { Namibia } & 10.62 & \text { No } \\ \text { Niger } & 176.2 & \text { Yes } \\ \text { Burundi } & 220.5 & \text { Yes } \\ \text { Malawi } & 241.2 & \text { Yes } \\ \text { Rwanda } & 642.5 & \text { Yes } \\ \text { C. African Rep. } & 2193.6 & \text { Yes }\end{array}$

Fixed broadband cost as percentage of GNI per capita in select African countries in 2013. Non-landlocked countries are connected by at least one submarine cable. Source: International Telecommunication Union (ITU).
DO SUBMARINE CABLES STIMULATE THE TRADE IN SERVICES? ARE THE HIGH COSTS JUSTIFIED BY THE POSSIBLE ECONOMIC RETURNS IN DEVELOPING COUNTRIES?
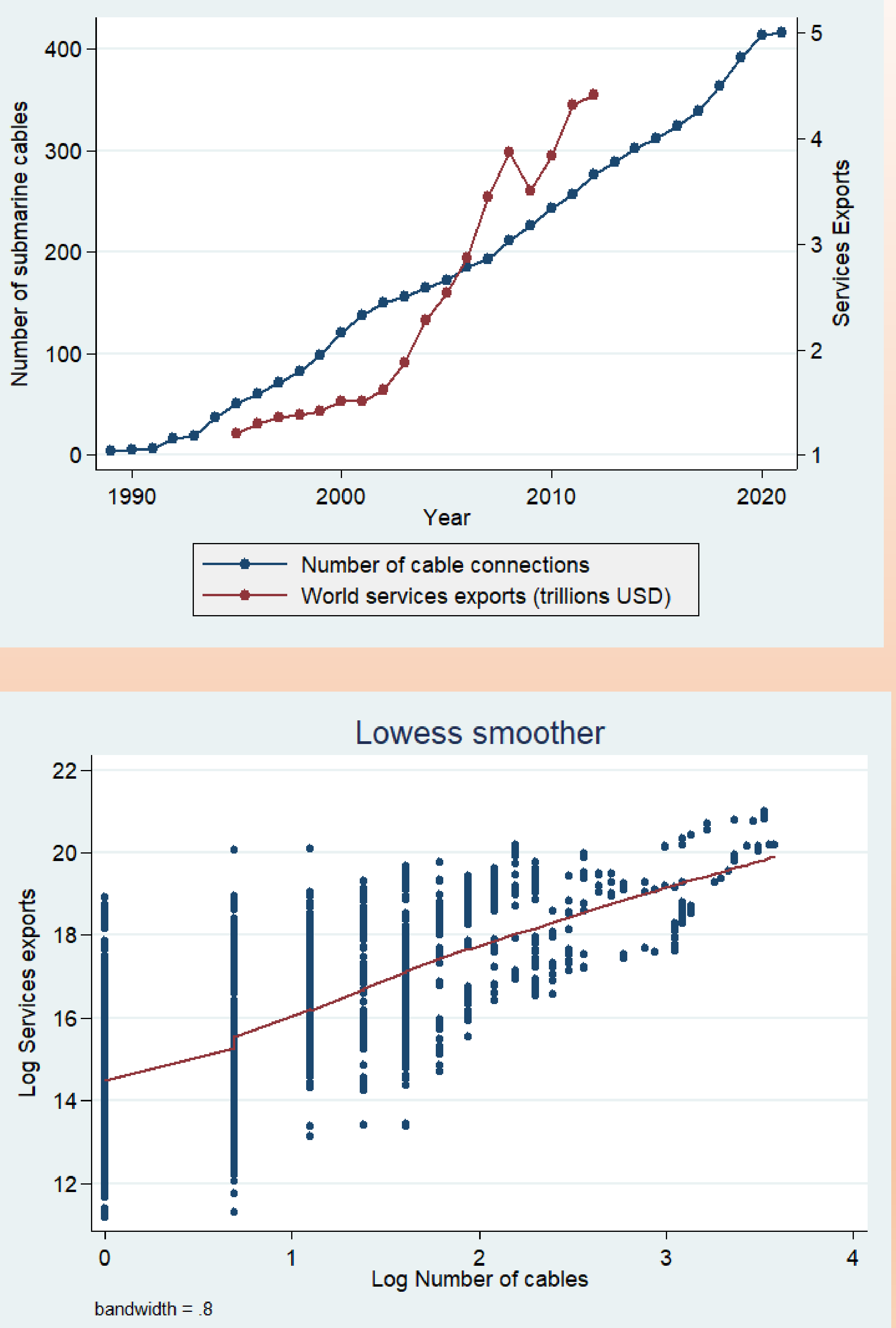

\section{Conclusions}

- Submarine cables are the cheapest, most reliable, and efficient way to connect countries to broadband internet.

- Submarine cables lead a large drop in broadband prices.

- This paper finds evidence that submarine cables lead to higher trade in services especially in developing countries.

- Investing in submarine cables would therefore aid in economic diversification efforts in these countries.

- Sectors that benefit from expanding services trade following connecting by submarine cables are: business, construction, and governmental services (exports) and business, transport and communication services (imports).

- This suggests a catch-up effect and higher gains from laying submarine cables in developing countries. 